Original Research Article

\title{
Pharmaco epidemiology of drugs used in post-cataract surgery patients in tertiary care hospital
}

\author{
Geetanjali Hiremath, Pankajkumar Masare*, Basavaraj C. Kotinatot
}

\begin{abstract}
Department of Pharmacology, Belagavi Institute of Medical Sciences, Belagavi, Karnataka, India
\end{abstract}

Received: 10 August 2018 Accepted: 31 August 2018

\section{*Correspondence to:}

Dr. Pankajkumar Masare, Email: geetahiremath28@ gmail.com

Copyright: (C) the author(s), publisher and licensee Medip Academy. This is an openaccess article distributed under the terms of the Creative Commons Attribution NonCommercial License, which permits unrestricted noncommercial use, distribution, and reproduction in any medium, provided the original work is properly cited.

\begin{abstract}
Background: In India cataract is the principal cause of blindness responsible for $62.6 \%$ as per national programme for control of blindness survey and as per our knowledge, very few systematically analysed data are available on the drug utilization study pattern of medical intervention for post cataract surgery in India. Hence, the present study was under taken to generate baseline drug use data and analyse various aspects of drug prescribing practices.

Methods: This study was conducted in department of ophthalmology BIMS Belagavi. A total of 449 patients' prescription was analysed prospectively. The data was analysed statistically, and results were expressed as numbers and percentage.

Results: A total of 2306 drugs were prescribed for 449 patients who underwent cataract surgery. All patients received topical eye drops includes bromfenac $0.1 \%$ eye drop and other one is a fixed drug combination of dexamathasone $0.1 \%$ plus ofloxacin $0.3 \%$ eye drop. Use of antibiotic in association with sex found to be significant ( $\mathrm{p}$ - value $<0.004)$. Average number of drugs per prescription was 5.1 and drugs which prescribed in generic name were $60.99 \%$ and overall percentage of drugs prescribed by brand name was $38.94 \%$ which includes $100 \%$ eye drops were prescribed by brand names. Fixed drug combination includes $19.50 \%$ and drugs from essential drug list used were $80.49 \%$.

Conclusions: Health care providers have to take initiative for rational prescribing keeping in mind that it is not only a matter of national policy but also to wellbeing of individual patient.
\end{abstract}

Keywords: Cataract, Drug utilization study, Eye drop, Pharmacoepidemiology

\section{INTRODUCTION}

Pharmaco-epidemiology is the application of epidemiological knowledge, methods, measurements, analysis and reasoning to study uses, cost effectiveness and adverse effect of drugs in defined population. ${ }^{1}$ Cataract causes $33 \%$ of blindness worldwide. In India cataract is the principal cause of blindness responsible for $62.6 \%$ as per NPCB survey 2006-2007.

WHO identifies cataract as one among the five major blinding eye conditions for immediate attention to achieve the goals of vision 2020. Cataract surgeries are commonly performed to prevent blindness. Vision 2020 aims to eliminate blindness due to cataract by performing cataract extraction with IOL implantation and also by increasing the number of cataract surgery rate., ${ }^{2,3}$

Cataract surgery is one of the most frequently performed elective surgical procedure throughout the country. The surgical methods have improved significantly with the advent of microsurgery. And the quality of treatment has dramatically improved hence complications have reduced, thus raising patients and surgeons' expectations of a successful visual outcome. ${ }^{4}$

Like other types of surgery, cataract surgery induces uncontrolled infection and inflammation which may leads to serious side effects such as hyphaema, iris prolapse, anterior uveitis, bacterial endopthalmitis and secondary glaucoma. ${ }^{5}$ Prevention and management of infection and 
inflammation is thus a mainstay in modern cataract surgery.

As the surgical procedure has become less invasive, the recovery after surgery is now easier and patients usually no longer require in-patient hospital care after the operation.

The modern minimally invasive cataracts surgery with phacoemulsification is considered as a minor procedure with an uneventful and pain-free recovery period.

However, little attention has been paid to pain and other postoperative ocular irritation symptoms, and the data on the incidence of these symptoms is conflicting. In some studies, rather few patients have reported any complaints after surgery. 6,7 Whereas in other studies some postoperative ocular irritation symptoms and pain have been experienced by the majority and even as many as $90 \%$ of patients. ${ }^{8-10}$ So this study was taken to analyse drugs used in post-operative cataract surgery patients prospectively.

\section{METHODS}

This prospective study was carried out in the department of pharmacology and ophthalmology BIMS Belagavi after obtaining approval and clearance from the institutional ethical committee for period of 6 month from $1^{\text {st }}$ December 2015 to $30^{\text {th }}$ May 2016.

\section{Inclusion criteria}

- Patients of either sex

- Age above 50 years operated for immature senile cataract.

\section{Exclusion criteria}

- Patients age bellow 50 years
- Cataract associated with diabetes, hypertension and other metabolic diseases.

The data was collected from the 449 inpatients who underwent cataract surgery in ophthalmology department and recorded in a proforma containing relevant demographic details like including their average number of drugs per prescription, number of encounters with antibiotics, analgesics, anti-inflammatory and other drugs, dosage form, route of administration, frequency and duration of therapy. These forms are used to analyse whether the drug is prescribed in generic or proprietary names.

\section{Statistical analysis}

Data were analysed using Microsoft Excel through statistical software: SPSS VERSION 22. All parameters were expressed in numbers and percentages. Chi-square test was used to see the association between different variables.

\section{RESULTS}

Out of 449 patients $287(63.92 \%)$ were female and 162 $(36.08 \%)$ were male, this shows female predominance in incidence of cataract and the most common symptom of patient was blurring of vision $357(79.51 \%)$ followed by patients who were accidently diagnosed with cataract during their refraction testing $14.92 \%$ and rest $5 \%$ accounts for complaints like watering of eye $10(2.22 \%)$, clouding of vision $13(2.89 \%)$ and halo with diplopia $2(0.44 \%)$. There was no much difference in incidence of cataract occurrence in both eyes i.e. Right eye constituting 247 $(55.02 \%)$ and left eye is $202(44.98 \%)$. Total 2306 drugs were prescribed post operatively in present study which were given in different dosage forms which are shown in table 6 , includes eye drops $100 \%$ a fixed dose combination (FDC) of dexamethasone plus ofloxacin eye drops (100\%) and bromfenac eye drops (100\%).

Table 1: Prescription summery.

\begin{tabular}{|c|c|c|c|c|}
\hline $\begin{array}{l}\text { Class of } \\
\text { drugs }\end{array}$ & Major therapeutic agent & $\begin{array}{l}\text { No. of cases } \\
\text { prescribed }(\%)\end{array}$ & $\begin{array}{l}\text { Route and } \\
\text { dosage form }\end{array}$ & Frequency and duration \\
\hline \multirow{2}{*}{ Antibiotics* } & Ofloxacin & $449(100)$ & $\begin{array}{l}\text { Eye drop } 0.3 \% \\
\text { solution }\end{array}$ & $\begin{array}{l}1 \text { drop } \times \text { every } 2 \mathrm{hrs} \text { for } \times 3 \mathrm{wk} \text {. } \\
1 \text { drop } \times \text { every } 4 \mathrm{hrs} / 4^{\text {th }}, 5^{\text {th }} \text {, and } 6^{\text {th }} \text { week }\end{array}$ \\
\hline & Ciprofloxacin & $374(83.29)$ & Tab 500mg P.O & $\begin{array}{l}\text { Twice daily } \times 5 \text { days. } \\
1 \text { day pre-op and } 4 \text { days post-op }\end{array}$ \\
\hline \multirow{2}{*}{ Analgesics } & Diclofenac & $374(83.29)$ & Tab 25mg P.O & Twice daily $\times 5$ days \\
\hline & Bromfenac & 449 (100) & $\begin{array}{l}\text { Eye drop } 0.1 \% \\
\text { solution }\end{array}$ & 1 drop $\times$ every 4 hrs for $\times 3 \mathrm{wk}$ \\
\hline Antacids & Ranitidine & $374(83.29)$ & Tab 150 P.O & $\begin{array}{l}\text { Twice daily } \times 5 \text { days. } \\
1 \text { day pre-op and } 4 \text { days post-op }\end{array}$ \\
\hline \multirow[t]{2}{*}{ Steroids } & $\begin{array}{l}\text { Dexamethasone in } \\
\text { combination with } \\
\text { ofloxacin }\end{array}$ & $449(100)$ & $\begin{array}{l}\text { Eye drop } 0.1 \% \\
\text { solution }\end{array}$ & $\begin{array}{l}1 \text { drop } \times \text { every } 2 \mathrm{hrs} \text { for } \times 3 \mathrm{wk} \text {. } \\
1 \text { drop } \times \text { every } 4 \mathrm{hrs} / 4^{\text {th }}, 5^{\text {th }} \text {, and } 6^{\text {th }} \mathrm{wk} \text {. }\end{array}$ \\
\hline & Dexamethasone & $283(63.80)$ & Inj 8mg IM & Stat \\
\hline
\end{tabular}

*Use of antibiotic in association with sex found to be significant ( $\mathrm{p}$ value $<0.004$ 
These two eye drops were found to be the most frequently prescribed drugs followed by oral tablets $83.29 \%$ which include one antibiotic (ciprofloxacin), analgesic (diclofenac) and ranitidine. Injections dexamethasone constitute $63.80 \%$ was the least prescribed drug in the present study and is shown in the Tables (Table 1 and Table 2).

Table 2: Association of antibiotic usage with sex.

\begin{tabular}{|lll|}
\hline & Female & Male \\
\hline Antibiotic use & 287 & 162 \\
\hline Chi-square test & 8.490 & 8.472 \\
\hline p- value & $<0.004$ & $<0.002$ \\
\hline
\end{tabular}

Table 3: Distribution based on chief complaints.

\begin{tabular}{|lll|}
\hline Chief complaints & $\begin{array}{l}\text { No. of } \\
\text { patients }\end{array}$ & $\begin{array}{l}\text { Percentage } \\
(\%)\end{array}$ \\
\hline Blurring of vision & 357 & 79.51 \\
\hline Refraction testing & 67 & 14.92 \\
\hline Clouding of vision & 13 & 2.89 \\
\hline Watering of eye & 10 & 2.22 \\
\hline Halo with diplopia & 2 & 0.44 \\
\hline
\end{tabular}

Table 4: WHO prescribing drug indicators.

\begin{tabular}{|lll|}
\hline Drug indicators & $\begin{array}{l}\text { No. of } \\
\text { patients }\end{array}$ & $\%$ \\
\hline Total drugs prescribed & 2302 & - \\
\hline $\begin{array}{l}\text { Average number of drugs per } \\
\text { prescription }\end{array}$ & 5.12 & - \\
\hline Drugs prescribed by brand names & 898 & 38.94 \\
\hline Drugs prescribed by generic name & 1404 & 60.99 \\
\hline Fixed drug combination & 449 & 19.50 \\
\hline Drugs from essential drug list & 1853 & 80.49 \\
\hline $\begin{array}{l}\text { No of drugs which are available in } \\
\text { hospital }\end{array}$ & 1404 & 60.99 \\
\hline $\begin{array}{l}\text { Drugs which are prescribed from } \\
\text { outside }\end{array}$ & 898 & 38.94 \\
\hline
\end{tabular}

WHO prescribing drug indicators shown in table 6 include, average number of drugs per prescription which was 5.1 and the range of drugs per prescription varied from 2 to 6 . Study also revealed that drugs which prescribed in generic name were $60.99 \%$ and overall percentage of drugs prescribed by brand name is $38.94 \%$ which includes $100 \%$ eye drops prescribed by brand names. Fixed drug combination includes $19.50 \%$ and drugs from essential drug list used were $80.49 \%$. Most of the drugs procured were from the hospital pharmacy and only few drugs are prescribed from outside (Table 3).

\section{DISCUSSION}

Authors analysed drug utilization of 449 patients prospectively who underwent cataract surgery. It was found that numbers of females $(63.92 \%)$ were more than males (36.08\%) showing female sex predominance. Present study is in contrast with study done by Prajwal P et al, where males $(56.01 \%)$ were more than females $(43.99 \%)$.

Cataract can occur in all age group, but it is a disease of older age group. The maximum number of patients in present study belongs to age group of 60-69 years (51\%), these finding shows were similar to study done by Kumar et al, where maximum patients belonged to age group above 60 years $(55.93 \%)$.

All patients received two eye drops. Analgesic, bromfenac eye drop $0.1 \%$ and combination of anti-inflammatory with antibiotic flouroquinolone that is a fixed drug combination of dexamathasone $0.1 \%$ plus ofloxacin $0.3 \%$ eye drops. $83.29 \%$ patients received oral therapy for 5 days post operatively with one antibiotic ciprofloxacin, one antiinflammatory and analgesic diclofenac given along with ranitidine.

Topically applied antibiotics are routinely used for the prophylaxis for postoperative bacterial ocular infections such as endophthalmitis. Flouroquinalones have good efficacy against the causative organism of endophthalmitis. In present study ofloxacin is being effective and it was the prescribed antibiotic in post-operative patients. This is similar to study done by Biswas et al, where ofloxacin was commonly prescribed. ${ }^{11}$ Whereas Kumar et al, has mentioned that newer fourth generation FQs moxifloxacin is more potent and with broad spectrum of activity to prevent endophthalmitis. ${ }^{12}$

Rational drug prescribing is defined as the use of the least number of drugs to obtain the best possible results in the shortest period and at a reasonable cost. ${ }^{13}$ In the present study, the average number of drugs per prescription was 5.1. WHO has recommended that average number of drugs per prescription should be two. ${ }^{14}$ In present study, the result reflects polypharmacy, Recommendation by WHO is not applicable as the patients included were in-patients who underwent surgery. In present study, the average length of stay was longer, there by more medication was prescribed. In such cases polypharmacy can be justifiable. Other hospital-based studies in India reported 3-5 drugs per prescription almost in the same range as present study. ${ }^{15-17}$ Polypharmacy is often associated with increased risk of drug interactions and adverse effects, higher cost and decreased compliance to patient. ${ }^{18,19}$ Hence, it is essential to keep the number of drugs per prescription as low as possible.

In present study, systemic antibiotic ciprofloxacin was prescribed orally twice daily for 5 days, but the benefit of systemic antibiotic therapy to prevent endophthalmitis remains controversial. Optimum antibiotic concentration in aqueous humor can be achieved by topical application. ${ }^{20,21}$ Authentic Indian document Vision 2020: The Right to sight publication - guideline for management of cataract in India (Vision 2020) clearly denies the need of systemic 
antibiotics on routine basis after post cataract surgery. ${ }^{22}$ High use of antibiotics reflects the condition of poor sanitation, nutrition, prevalence of various infections and certain acute infective conditions which needs conservative treatment.

The other most commonly prescribed agent was NSAIDs and corticosteroid along with an antibiotic mainly a fixed dose combination. Corticosteroids were the main antiinflammatory drugs prescribed post operatively before the advent of NSAIDs. NSAIDs as anti-inflammatory drugs in postoperative cataract patients have some advantages producing analgesia and sustained pupillary dilatation during intra-operative preventing postoperative cystoid macular edema and reducing different intra-and extraocular inflammation. ${ }^{23}$ Several trials have established that topical NSAIDs have a number of important roles in the treatment of inflammation following ophthalmic cataract surgery and some were more advantageous over steroids. ${ }^{24}$

A study done by Flach AJ et al, conclude that advantage of NSAIDs over corticosteroids include a reduction in postoperative pain and photophobia, decreased itching in allergic conjunctivitis, decrease in ocular pressure and reduction of intra-operative miosis. ${ }^{25}$ Depending on severity of inflammation and prolonged surgery, $63.02 \%$ patients received Inj dexamethasone intramuscularly apart from topical application.

Fixed dose combination of drugs prescribed were $19.50 \%$ which was less compared to the other studies done by Kshirasagaretal.26 where $36.9 \%$ FDC were prescribed.

The percentage of drugs dispensed from the hospital pharmacy was $60.99 \%$ as there were more drugs available which was in contrast to the study Narwane et al, $36.78 \%$ drugs were not available in hospital pharmacy. ${ }^{27}$

In present study, authors found that written instructions regarding dose, dosing interval and duration of therapy were clearly mentioned in all the prescriptions. Whereas earlier study of drug use pattern in ophthalmology from India shows $30 \%$ incomplete prescriptions. ${ }^{28}$ Instructions regarding drug instillation is important aspect of ocular therapy. ${ }^{29}$ Patients were asked to put only one drop of the drug which was clearly written in all prescriptions but patients usually have the habit of applying 2-3 drops in the eye resulting into the wastage, increased cost and poor compliance, About the same was informed to all patients in present study. ${ }^{30}$

FDC Dexamethasone plus ofloxacin treatment strategy was found to be the cheapest among another drug therapy and bromfenac eye drop was costlier. These were prescribed for all 449 patients in present study. Average total cost per patient was $115.00 \mathrm{INR}$. The results were similar to the earlier studies done by Goyal et al, and Narwane et al, where the cost paid by the patient was significantly higher than that paid by the Hospital pharmacy $(p<0.0001) .{ }^{31}$

\section{CONCLUSION}

To conclude, fluoroquinolines and corticosteroids were the most frequently prescribed drug groups in post cataract surgery patients. The other most commonly prescribed agent was NSAIDs as anti-inflammatory and analgesic, the advent of NSAIDs in management of post cataract surgery patients over and above the steroids was proven with many studies and was included accordingly in the present study. Rational prescribing is an important criterion for convenience of a patient in terms of disease, adverse events and treatment cost. Study data may be helpful to understand the need of writing generic name in prescriptions, adherence with the National essential drugs list policy and availability of chief alternative medicines in hospital pharmacy. Health care providers have to take initiative for rational prescribing keeping in mind that it is not only a matter of national policy but also to wellbeing of individual patient.

Dosing intervals and duration of therapy of combined topical antibiotic and steroid treatment postoperatively matched with Indian document Vision 2020. This is a positive phenomenon towards rationalization and homogeneity in the treatment part. It also increases the quality management of cataract in India.

Funding: No funding sources

Conflict of interest: None declared

Ethical approval: The study was approved by the Institutional Ethics Committee

\section{REFERENCES}

1. Maiti Rituparna. Pharmacoepidemiology. Postgraduate topics in pharmacology. Paras Medical Books, Hyderabad, $2^{\text {nd }}$ Ed.; 2015:206-217.

2. World Health Organization. Available at: http://www.who.int/blindness/causes. Accessed 7 September 2017.

3. Park K. Epidemiology of chronic non-communicable Diseases and conditions. Parks text book of preventive and social medicine, Bhanarasi Bhanot publishers, Jabalapur, 24 ${ }^{\text {th }}$ Ed.; 2017:419-420.

4. Bergman U, Andersen M, Vaccheri A, Bjerrum L, Wettermark B, Montanaro N. Deviations from evidence-based prescribing of nonsteroidal antiinflammatory drugs in three European regions. Eur $\mathbf{J}$ Clin Pharmacol. 2000;56:269-72.

5. Khurana AK, Bhawana Khurana. Diseases of lens. Comphrensive Ophthalmology. Jaypee Brothers Publishers, New Delhi, 6 ${ }^{\text {th }}$ Ed.; 2015:210-212.

6. Camesasca FI, Bianchi C, Beltrame G, Caporossi A, Piovella M, Rapisarda A, et al. Italian BetamethasoneChloramphenicol vs Dexamethasone-Tobramycin Combination Study Group. Control of inflammation and prophylaxis of endophthalmitis after cataract surgery: a multicenter study. Eur J Ophthalmol 2007; 17:733-42. 
7. Raizman MB, Donnenfeld ED, Weinstein AJ. Clinical comparison of two topical prednisolone acetate $1 \%$ formulations in reducing inflammation after cataract surgery. Curr Med Res Opinion. 2007 Oct 1;23(10):2325-31.

8. Stifter E, Menapace R. Instant vision compared with postoperative patching: clinical evaluation and patient satisfaction after bilateral cataract surgery. Am J Ophthalmol 2007;143:441-8.

9. Heuermann T, Anders N, Rieck P, Hartmann C. Peribulbar aesthesia and prophylaxis of postoperative endophthalmitis after cataract surgery. J Cataract Refract Surg. 2000;35:1523-31.

10. Pianini V, Passani A, Rossi GC, Passani F. Efficacy and safety of netilmcin/dexamethasone preservative free and to bramycin/dexamethasone-preserved fixed combination in patients after cataract surgery. J Ocular Pharmacol. 2010;26:617-21.

11. Biswas S, Mondal KK, Halder S, Sarkar SS, Maiti T, Lahiri SK, et al Pharmaco-epidcemiology of drugs utilised for cataract surgery in a government medical college and hospital. J Indian Med Assoc. 2010 Dec;108(12):829-32.

12. Agrawal NK, Gupta N. Pharmaco-epidemiology of drugs used in post cataract surgery patients in tertiary care hospital in north India - a prospective observational study. World J Pharmaceut Res. 2015:4(06):1618-28.

13. Shankar PR, Upadhyay DK, Subish P, Bhandari RB, Das B. Drug utilisation among older inpatients in a teaching hospital in Western Nepal. Singapore Med J. 2010 Jan 1;51(1):28.

14. Gross F, Drug utilization therapy and practice. The present situation in Federal Republic of Germany. Eurp J Clin Pharmacol. 1981;19:387-94.

15. Maini R, Verma KK, Biswas NR, Agrawal SS. Drug utilization study in dermatology in a tertiary hospital in Delhi. Indian J Physiol Pharmacol. 2002 Jan 25;46(1):107-10.

16. George KK, Narmadha S, Nagarajan M. A study on drug prescribing pattern in Madurai city. Indian $\mathbf{J}$ Pharmacol. 2002 Sep 1;34(5):361.

17. Sharma SC, Uppal R, Sharma PL, Kaur S. Rational use of topical corticosteroids in dermatology. Indian $\mathrm{J}$ Pharmacol. 1990 Jul 1;22(3):141.

18. Rambhade S, Chakarborty A, Shrivastava A, Patil UK, Rambhade A. A survey on polypharmacy and use of inappropriate medications. Toxicol Int. 2012;19(1):68-73.

19. Nolan L, O'Malley K. Prescribing for the elderly part I: sensitivity of the elderly to adverse drug reactions. J Am Geriatrics Soc. 1988 Feb;36(2):142-9.

20. Jensen MK, Fiscella RG, Moshirfar M, MooneyB. Third and fourth generation fluoroquinolones: Retrospective comparison of endophthalmitis after cataract surgery performed over 10 years. J Cataract Refract Surg. 2008;34:1460-7.
21. Endophthalmitis Vitrectomy Study (EVS) Groups. A randomized trial of immediate vitrectomy and of intravenous antibiotics for the treatment of postoperative bacterial endophthalmitis: results of endophthalmitis vitrectomy study. Arch Ophthalmol. 1995;113:14798-896.

22. Vision 2020 India: The Right to sight publication guideline for management of cataract in India. Postoperative Medications. 2011:24-25.

23. Ursell PG, Spalton DJ, Whitcup SM, Nussenblatt RB. Cystoid macular edema after phacoemulsification: relationship to blood-aqueous barrier damage and visual acuity. J Cataract Refractive Surg. 1999 Nov 1;25(11):1492-7.

24. Yadav AK, Patel V. Drug use in primary open angle glaucoma: A prospective study at a tertiary care teaching hospital. Indian J Pharmacol. 2013 Mar;45(2):117-20.

25. Flach AJ. Topical nonsteroidal antiinflammatory drugs in ophthalmology. Int Ophthalmol Clin. 2002 Jan 1;42(1):1-1.

26. Kshirsagar M, Langade D, Patil S, Patki PS. Prescribing patterns among medical practitioners in Pune, India. Bull World Health Organization. 1998;76(3):271.

27. Narwane SP, Patel TC, Shetty YC, Chikhalkar SB. Drug utilization and cost analysis of eye diseases in ophthalmology OPD of an Indian tertiary care hospital - a prescription survey. $\mathrm{Br} \mathrm{J}$ Pharmaceut Res. 2011;1(1):9-18.

28. Biswas NR, Jindal S, Siddiquei MM, Maini R. Patterns of prescription and drug use in ophthalmology in a tertiary hospital in Delhi. Br J Clin Pharmacol. 2001 Mar;51(3):267-9.

29. Flach AJ. The importance of eyelid closure and nasolacrimal occlusion following the ocular instillation of topical glaucoma medications, and the need for the universal inclusion of one of these techniques in all patient treatments and clinical studies. Transactions of the Am Ophthalmological Society. 2008 Dec;106:138.

30. Gautam CS, Sangeetha B, Goel NK, Suresh KG, Sood S. Instillation of drugs in the eye: Importance of proper instructions to patients. Indian J Pharmacol. 2001 Sep 1;33(5):386.

31. Goyal S, Samant BD, Parkar S.R. Pharmacoeconomic study of psychotropic drug use in psychiatry outpatient department in tertiary care teaching hospital in western India. Indian J Pharmacol. 2008;40:28.

Cite this article as: Hiremath $\mathrm{G}$, Masare $\mathrm{P}$, Kotinatot BC. Pharmaco epidemiology of drugs used in post-cataract surgery patients in tertiary care hospital. Int J Basic Clin Pharmacol 2018;7:2031-5. 